\title{
Comparison of propo- fol versus thiopentone with midazolam or lidocaine to facilitate laryngeal mask insertion
}

Pramod Bapat MD FRCA, Ravindra N. Joshi MD FFARCSI, Edward Young FRCA, Roger H. Jago FRCA
Purpose: To assess the ease of insertion of laryngeal mask airway (LMA) comparing propofol with lidocaine or midazolam followed by thiopentone and compare the costs with each technique.

Methods: One hundred and fifty ASA I or 2 patients equally divided into three groups scheduled for elective surgery were recruited into this prospective, single blind, randomized, parallel groups study. Anaesthetic induction was achieved with I $\mu \mathrm{g} \cdot \mathrm{kg}^{-1}$ fentanyl iv followed by either $2.5 \mathrm{mg} \cdot \mathrm{kg}^{-1}$ propofol (group P), or a sequence of $1.5 \mathrm{mg} \cdot \mathrm{kg}^{-1}$ lidocaine and 5 $m g \cdot \mathrm{kg}^{-1}$ thiopentone (group LT), or midazolam $0.1 \mathrm{mg} \cdot \mathrm{kg}^{-1}$ and, three minutes later, $5 \mathrm{mg} \cdot \mathrm{kg}^{-1}$ thiopentone (group MT). The LMA was inserted by the blinded anaesthetist who assessed and graded the conditions for LMA insertion and noted any adverse responses (i.e., inadequate jaw relaxation, gagging, coughing, limb or head movement, hiccough and laryngospasm). Conditions were considered "excellent" if there were no adverse responses, and "satisfactory" if such a response was mild and transient.

Results: Excellent or satisfactory conditions were observed in 48 (96\%) patients in the midazolam-thiopentone group. 46 (92\%) in the propofol group, and 34 (68\%) in the lidocainethiopentone group $(P=0.0001)$. The incidence of gagging ( $P$

\section{Key words}

ANAESTHETICS, INTRAVENOUS: propofol, thiopentone,

midazolam;

ANAESTHETICS, LOCAL: lidocaine;

EQUIPMENT: laryngeal mask.

From the Department of Anaesthetics, Royal Berkshirc Hospital, Reading RGI SAN, United Kingdom.

Address correspondence to: Dr. Pramod Bapat, Department of Anaesthetics, Royal Berkshire Hospital, Reading RG1 5AN, United Kingdom.

Accepted for publication 17th February, 1996.
$=0.042)$, limb movement $(P=0.031)$, and laryngospasm $(P=$ $0.0001)$ was higher in the lidocaine-thiopentone group.

Conclusions: With the above doses, a fentanyl-midazolamthiopentone combination which is about 35\% less expensive than fentanyl-propofol, provides equally good conditions for the insertion of LMA.

Objectif: Évaluer la facilité d'insertion du masque laryngé (ML) en comparant le propofol avec l'association lidocaïne ou midazolam-thiopentone et les coûts entraînés par chacune des techniques.

Méthodes: Cent cinquante patients ASA 1 et 2 répartis également en trois groupes, programmés pour une chirurgie non urgente étaient admis dans cette étude prospective, à l'aveugle, aléatoire et en groupes parallèles. L'induction était réalisée avec fentanyl $1 \mathrm{\mu g} \cdot \mathrm{kg}^{-1}$ iv suivi soit par du propofol 2,5 $\mathrm{mg} \cdot \mathrm{kg}^{-1}$ (groupe $P$ ), ou une séquence de lidocaïne $1,5 \mathrm{mg} \cdot \mathrm{kg}^{-1}$ et thiopentone $5 \mathrm{mg} \mathrm{kg}^{-1}$ (groupe LT), ou midazolam 0,1 $\mathrm{mg} \cdot \mathrm{kg}^{-1}$ (groupe MT) suivis trois minutes plus tard de thiopentone $5 \mathrm{mg} \cdot \mathrm{kg}^{-1}$. Le ML était inséré par un anesthésiste neutre qui évaluait et classait les conditions d'insertion du $M L$, et notait toute condition défavorable (c. à d., relaxation de la mâchoire insuffisante, réflexe nauséeux, toux, mouvement de la tête ou des membres, hoquet ou spasme laryngé). Les conditions étaient considérées comme excellentes si aucune réaction défavorable n'était constatée, et satisfaisante, si la réaction n'était que légère ou transitoire.

Résultats: On a constaté des conditions excellentes ou satisfaisante chez 48 (96\%) des patients du groupe midazolamthiopentone, chez 46 (92\%) du groupe propofol et 34 (68\%) du groupe lidocaine-thiopentone $(P=0,0001)$. L'incidence de réflexes nauséeux $(P=0,042)$, mouvements des membres $(P=$ $0,031)$ et de spasme laryngé $(P=0,0001)$ était plus élevée dans le groupe lidocaïne-thiopentone.

Conclusions: Aux doses mentionnées, la combinaison fentanyl-thiopentone procure d'aussi bonnes conditions pour l'insertion du $M L$ que la combinaison fentanyl-propofol et coûte environ $35 \%$ moins cher. 
The laryngeal mask airway (LMA) ${ }^{\prime}$ has gained widespread popularity for airway management during surgery. Intravenous (iv) propofol with or without an opioid has been shown to be the induction agent of choice for its insertion in patients breathing spontaneously. ${ }^{2-5}$ Propofol depresses airway reflexes more than thiopentone ${ }^{6}$ and therefore allows easy insertion of the LMA with reduced incidence of side effects e.g., coughing, gagging or laryngospasm. If controlled ventilation is planned, other iv anaesthetic agents and a muscle relaxant can be used to facilitate LMA insertion.?

However, propofol is expensive and may not be available for regular use world-wide. A less expensive and equally effective induction technique would be a useful alternative. Lidocaine or midazolam used as adjuvants to thiopentone may decrease the incidence of adverse responses to insertion of the LMA. Lidocaine iv has been used previously to suppress the cough reflex ${ }^{8.9}$ and the stress response to laryngoscopy. ${ }^{10,11}$ It is cheap and easily available. A recent study ${ }^{12}$ has shown that lidocaine, used as an adjuvant to propofol, improves conditions for LMA insertion. Midazolam is less expensive than propofol and has been shown to have a synergistic action with thiopentone. ${ }^{13}$ It also. has a relatively short elimination half life $(1-4 \mathrm{hr} .)^{.14}$ The combination of lidocaine or midazolam with thiopentone for LMA insertion has not been reported. We considered that either of these drugs given before thiopentone may obtund airway reflexes sufficiently to allow satisfactory insertion of LMA at a lesser cost.

The aim of this study was to assess the ease of insertion of LMA comparing propofol with either a sequence of lidocaine and thiopentone, or midazolam and thiopentone and to consider the cost implications.

\section{Methods}

After ethical approval by the local research ethics committee, 150 ASA 1 or 2 adult patients scheduled for elective gynaecological, orthopaedic or general surgical procedures were entered in this study. All the patients gave informed consent. Both in-patients and day cases were included in the study. During the preoperative assessment, a history of smoking and alcohol consumption were noted. The in-patients were given $20 \mathrm{mg}$ temazepam $p o$ as premedication about $60-90 \mathrm{~min}$ before surgery.

Patients were randomized to receive one of the combinations of drugs for induction of anaesthesia. On arrival in the anaesthetic room ECG, oxygen saturation and non-jnvasive blood pressure monitoring were instituted. After preoxygenation, all patients received $1 \mu \mathrm{g} \cdot \mathrm{kg}^{-1}$ fentanyl iv. Anaesthesia was induced one minute later with $2.5 \mathrm{mg} \cdot \mathrm{kg}^{-1}$ propofol (Group P) $i v$, or
$1.5 \mathrm{mg} \cdot \mathrm{kg}^{-1}$ lidocaine followed $30 \mathrm{sec}$ later by 5 $\mathrm{mg} \cdot \mathrm{kg}^{-1}$ thiopentone (Group LT), or midazolam 0.1 $\mathrm{mg} \cdot \mathrm{kg}^{-1}$ followed three minutes later by $5 \mathrm{mg} \cdot \mathrm{kg}^{-1}$ thiopentone (Group MT). The LMA (women size \#3; men size \#4) lubricated with water soluble jelly (K-Y) was inserted by the method described by Brain, ${ }^{2}$ one minute after the induction of anaesthesia by one of the investigators (EY or RHJ) who was unaware of the drugs used. He noted any occurrence of the following adverse responses: inadequate jaw relaxation, gagging, coughing, limb or head movement, hiccoughs and laryngospasm. A bolus of propofol was given to deepen the anaesthetic to facilitate the insertion, if desired by the investigator inserting the LMA. A response was graded as mild if it was transient and minimal; moderate if this lasted more than a few seconds but resolved within 20 sec; and severe if it was sustained or needed propofol to allow LMA insertion. The overall ease of insertion of LMA was assessed as excellent, satisfactory or poor on a three point scale. Absence of any adverse response denoted excellent conditions, and a mild response not affecting the ease of insertion meant satisfactory conditions. Conditions were considered poor if the patient demonstrated moderate or severe adverse responses to LMA insertion, or if additional $i v$ anaesthetic agent was required to deepen the anaesthetic level (bolus of propofol).

After insertion of the LMA, anaesthesia was continued with $\mathrm{N}_{2} \mathrm{O} 66 \%$ in $\mathrm{O}_{2}$ and isoflurane $2 \%$. Manual ventilation was employed if necessary. The study ended when the patient was considered to have reached an adequate depth of inhalational anaesthesia.

The data were analysed using Student's $t$ test, a chi squared test or Fisher's exact test as appropriate. The $5 \%$ level of probability $(P<0.05)$ being taken as significant. The effect of the sex of the patient was analysed by fitting a linear logistic model.

\section{Results}

One hundred and fifty patients were equally and randomly divided into three groups. The groups were similar in the age and the weight of the patients but there were more women in group LT than in the other groups $(P=0.0279)$. The incidence of premedication, smoking and alcohol consumption was similar in all groups (Table I).

Insertion of the LMA was assessed as poor in 16 (32\%) patients $(P=0.0001)$ in group LT, $4(8 \%)$ in group $P$ and $2(4 \%)$ in group MT (Figure). For all three groups the proportion of patients with a satisfactory assessment was about $1 / 3$ of the patients graded either satisfactory or excellent. We therefore compared the proportion of all the patients who were graded either 
TABLE I Demographic data and incidence of premedication, smoking and alcohol consumption

\begin{tabular}{lllll}
\hline & $\begin{array}{l}\text { Lidocuinel } \\
\text { Propofol } \\
n=50\end{array}$ & $\begin{array}{l}\text { Thiopentone } \\
n=50\end{array}$ & $\begin{array}{l}\text { Midazolam } \\
\text { Thiopentone } \\
n=50\end{array}$ & $P$ \\
\hline M/F & $27 / 23$ & $15 / 35$ & $26 / 24$ & 0.027 \\
Age: yr (SD) & $43.1(14.6)$ & $45.6(12.7)$ & $42.9(13.9)$ & NS \\
Weight: kg (SD) & $72.3(10.4)$ & $68.5(11.2)$ & $69.5(13.9)$ & NS \\
Premedication & $18(36 \%)$ & $22(44 \%)$ & $21(42 \%)$ & NS \\
Smoking & $15(30 \%)$ & $14(28 \%)$ & $13(26 \%)$ & NS \\
Alcohol & $29(58 \%)$ & $27(54 \%)$ & $35(70 \%)$ & NS \\
\hline
\end{tabular}

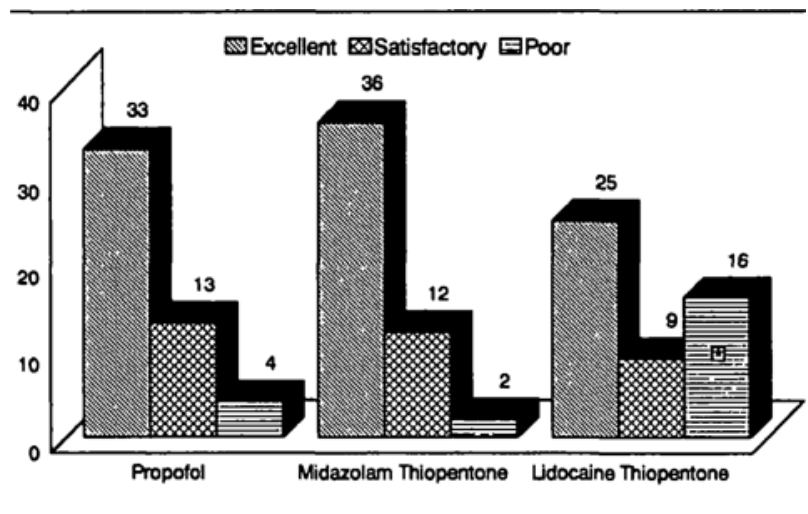

FIGURE Overall assessment of LMA insertion. ${ }^{*}$ LT group has significantly high number of poor insertions $=(P<0.0001)$.

TABLE II Overall assessment of LMA insertion

\begin{tabular}{lllll}
\hline & $\begin{array}{l}\text { Lidocainel } \\
\text { Thiopentone }\end{array}$ & $\begin{array}{l}\text { Midazolam/ } \\
\text { Thiopentone } \\
n=50\end{array}$ & $P$ \\
Assessment & $n=50$ & $n=50$ & $n=50$ & $0.0001^{*}$ \\
\hline $\begin{array}{l}\text { Excellent and } \\
\text { Satisfactory }\end{array}$ & $46(92 \%)$ & $34(68 \%)$ & $48(96 \%)$ & \\
\begin{tabular}{l} 
Poor \\
\hline
\end{tabular} & $4(8 \%)$ & $16(32 \%)$ & $2(4 \%)$ & $0.0001^{*}$ \\
\hline
\end{tabular}

*Group P and MT compared with LT.

excellent or satisfactory (Table II). Groups P and MT were similar to each other, and superior conditions for LMA insertion were observed in both these groups compared with group LT $(P=0.0001)$. The proportion of the patients graded as poor or satisfactory who received premedication, smoked or consumed alcohol was similar in all three groups (Table III).

Because the proportion of women was higher in group LT than in groups P and MT, an analysis was required to determine whether the poorer performance of the group LT was related to the sex of the patients. A linear logistic model containing terms representing all the treatment groups and the sex of the patient was fitted
TABLE III Influence of premedication, smoking and alcohol consumption of the patient on LMA insertion in patients with conditions graded poor or satisfactory

\begin{tabular}{lccll}
\hline & Propofol & $\begin{array}{l}\text { Lidocainel } \\
\text { Thiopentone } \\
n=25\end{array}$ & $\begin{array}{l}\text { Midazolain } \\
\text { Thiopentone } \\
n=14\end{array}$ & $P$ \\
\hline Premedication & $6(35.3 \%)$ & $6(24.0 \%)$ & $5(35.7 \%)$ & NS \\
Smoking & $6(35.3 \%)$ & $5(20.0 \%)$ & $3(21.4 \%)$ & NS \\
Alcohol & $10(58.8 \%)$ & $14(56.0 \%)$ & $9(64.3 \%)$ & NS \\
\hline
\end{tabular}

TABLE IV Lincar logistic model for group and sex of the patients, with fitted and obscrved probabilitics for obtaining excellent or satisfactory condition

\begin{tabular}{|c|c|c|c|}
\hline \multirow[b]{2}{*}{ Sex } & \multirow[b]{2}{*}{ Group } & \multicolumn{2}{|c|}{$P$ (Excellenu/Satisfactory) } \\
\hline & & Finted & Observed \\
\hline \multirow[t]{3}{*}{$\mathbf{M}$} & $\mathbf{P}$ & 0.894 & 0.889 \\
\hline & LT & 0.551 & 0.600 \\
\hline & MT & 0.946 & 0.923 \\
\hline \multirow[t]{3}{*}{$\mathbf{F}$} & $\mathbf{P}$ & 0.950 & 0.956 \\
\hline & LT & 0.735 & 0.714 \\
\hline & MT & 0.975 & 1.000 \\
\hline
\end{tabular}

TABLE $V$ Incidence of side effects

\begin{tabular}{lllll}
\hline & $\begin{array}{l}\text { Propofol } \\
n=50\end{array}$ & $\begin{array}{l}\text { Lidocainef } \\
\text { Thiopentone } \\
n=50\end{array}$ & $\begin{array}{l}\text { Midazolam } \\
\text { Thiopentone } \\
n=50\end{array}$ & $P$ \\
\hline Assessment & $12(24 \%)$ & $11(22 \%)$ & $3(6 \%)$ & NS \\
\hline $\begin{array}{l}\text { Inadequatc jaw } \\
\quad \text { relaxation }\end{array}$ & & & & \\
Gagging & $4(8 \%)$ & $11(22 \%)^{*}$ & $3(6 \%)$ & 0.042 \\
Coughing & $1(2 \%)$ & $1(2 \%)$ & $2(4 \%)$ & NS \\
Limb movement & $8(16 \%)$ & $12(24 \%)^{*}$ & $2(4 \%)$ & 0.031 \\
Head movement & $2(4 \%)$ & $1(2 \%)$ & $3(6 \%)$ & NS \\
Hiccoughs & $1(2 \%)$ & $2(4 \%)$ & $7(14 \%) \dagger$ & 0.032 \\
Laryngospasm & 0 & $14(28 \%)^{*}$ & $3(6 \%)$ & 0.0001 \\
\hline
\end{tabular}

*Significant, compared with Propofol and Midazolam-Thiopentone groups.

†Compared with Propofol and Lidocaine-Thiopentone groups.

and showed that the sex of the patient had no effect on the outcome (Table IV).

The main difference between the three groups was the occurrence of gagging in $11(22 \%)(P=0.042)$, limb movement in $12(24 \%)(P=0.031)$ and laryngospasm in $14(28 \%)(P=0.0001)$ patients in group LT compared with groups $P$ and $M T$. The incidence of hiccough was higher in group $C(P=0.032)$ than in groups $P$ and $L T$ (Table V).

\section{Discussion}

Propofol is particularly well suited for the insertion of the LMA because of its greater depressant effect on airway reflexes than that of thiopentone. ${ }^{6}$ Brown $e t a l^{3}$ 
compared propofol with thiopentone and found that thiopentone alone was associated with a higher incidence of gagging on LMA insertion and that propofol was more effective in providing satisfactory conditions.

Scanlon et al. ${ }^{4}$ also compared the conditions for LMA insertion after either propofol $\left(2.5 \mathrm{mg} \cdot \mathrm{kg}^{-1}\right)$ or thiopentone $\left(5 \mathrm{mg} \cdot \mathrm{kg}^{-1}\right)$. However, their patients received assisted ventilation for two minutes with isoflurane $2 \%$ in oxygen $50 \%$ and nitrous oxide via a face mask before the insertion of the LMA. They showed that thiopentone was associated with a higher incidence of adverse responses $(76 \%)$ than was propofol $(26 \%)$. It is suggested that thiopentone increases airway irritability because of the relatively greater depressant effect of the drug on the sympathetic than on the parasympathetic reflex arch. ${ }^{15}$ It is clear that successful insertion with thiopentone would require either adequate reflex suppression or a deeper plane of anaesthesia.

We used $1.5 \mathrm{mg} \cdot \mathrm{kg}^{-1}$ lidocaine $\mathrm{iv}$, because this dose has been shown to be effective for the suppression of cough reflex in both awake ${ }^{8}$ and anaesthetised patients. ${ }^{9}$ The use of lidocaine prior to thiopentone in our patients was associated with a lower incidence of side effects than in those of Scanlon et al. ${ }^{4}$

The conditions for LMA insertion were excellent in $50 \%$ and satisfactory in $18 \%$, but were poor in $32 \%$ of patients.

We used midazolam because it does not enhance airway reactivity and has a synergistic effect with thiopentone. ${ }^{13}$ It also has a relatively short elimination half-life $(1-4 \mathrm{hr}) .^{14}$ With a dose of midazolam $0.1 \mathrm{mg} \cdot \mathrm{kg}^{-1}$ most of the patients were sleepy though easily rousable. A pre-calculated dose of thiopentone $\left(5 \mathrm{mg} \cdot \mathrm{kg}^{-1}\right)$ was used because the aim was a deeper plane of anaesthesia with greater suppression of airway reflexes. Thiopentone was given three minutes after midazolam because the peak effect of $i v$ midazolam is observed after four minutes ${ }^{13}$ and it is essential that the peak eftects of both thiopentone and midazolam coincide to provide optimal conditions.

The midazolam and thiopentone combination provided excellent conditions in $72 \%$ and satisfactory in $24 \%$ patients. These are comparable with those of propofol which were $66 \%$ and $26 \%$ respectively.

We randomised the patients into different groups by assigning them a number before they were entered into this study, but more women were recruited in group LT and this predominance could have been avoided if we had stratified by sex. We applied logistic regression analysis to evaluate the effect of sex on LMA insertion. This analysis showed that there was no influence of sex on the results (Table IV).

Recently, Stoneham et al. ${ }^{12}$ compared saline-propofol
TABLE VI Cost of the drugs

\begin{tabular}{|c|c|c|c|}
\hline \multirow[b]{2}{*}{ Drug } & \multicolumn{3}{|c|}{ Prices in Pounds sterling } \\
\hline & Group $P$ & Group LT & Group $M T$ \\
\hline $\begin{array}{l}\text { Fentanyl }(100 \mu \mathrm{g}) \\
\quad 2 \mathrm{ml}\end{array}$ & 0.24 & 0.24 & 0.24 \\
\hline $\begin{array}{l}\text { Propofol (200 mg) } \\
20 \mathrm{ml}\end{array}$ & 3.88 & - & - \\
\hline $\begin{array}{l}\text { Thiopentone }(500 \mathrm{mg}) \\
+ \text { Water for Injection } \\
20 \mathrm{ml}\end{array}$ & - & 1.45 & 1.45 \\
\hline $\begin{array}{l}\text { Lidocaine (100 mg) } \\
\qquad 10 \mathrm{ml}\end{array}$ & - & 0.30 & - \\
\hline $\begin{array}{l}\text { Midazolam (10 mg) } \\
\quad 5 \mathrm{ml}\end{array}$ & - & - & 1.01 \\
\hline Total cosi & 4.12 & 1.99 & 2.70 \\
\hline Savings & & $48 \%$ & $35 \%$ \\
\hline
\end{tabular}

Sourcc: British National Formulary, No.30 (Sept. 1995); A joint publication of British Medical Association and the Royal Pharmacological Socicty of Greal Britain.

with lidocaine-propofol combination for LMA insertion and reported a high incidence of difficulties (38\%) and airway obstruction $(25 \%)$ with propofol alone, but the patients in their study received propofol at a relatively slow rate of $600 \mathrm{ml} \cdot \mathrm{hr}^{-1}\left(10 \mathrm{ml} \cdot \mathrm{min}^{-1}\right)$ for induction. Our results with propofol show a much lower incidence of poor insertion (8\%), and none of our patients had airway obstruction. Fentanyl iv given to our patients may have contributed in improving the conditions for the LMA insertion.

Comparison of the costs incurred by using these three combinations is shown in Table VI. Approximately 24,000 anaesthetics are administered annually at the hospital where this study was carried out. The LMA is used in about $60 \%$ of these patients (departmental audit). Even if propofol is considered necessary for many of these e.g., day cases, we feel that a midazolamthiopentone combination could be a suitable alternative in approximately five to six thousand patients, saving up to $£ 8400$ in one year.

To conclude, our results show that fentanyl $1 \mu \mathrm{g} \cdot \mathrm{kg}^{-1}$ and midazolam $0.1 \mathrm{mg} \cdot \mathrm{kg}^{-1}$ iv followed three minutes later by thiopentone $5 \mathrm{mg} \cdot \mathrm{kg}^{-1}$ is equally effective in providing optimal conditions compared with fentanyl 1 $\mu \mathrm{g} \cdot \mathrm{kg}^{-1}$ and propofol $2.5 \mathrm{mg} \cdot \mathrm{kg}^{-1}$ for the insertion of LMA in ASA grade $I$ or 2 patients and is a viable and less expensive alternative.

\section{Acknowledgements}

The authors wish to express their thanks to surgical colleagues, operating theatre and recovery staff at the Royal Berkshire hospital in Reading for their co-opera- 
tion in conducting this study. We are grateful to Professor R.N. Curnow of the Department of Applied Statistics, University of Reading, for his help in data analysis.

\section{References}

1 Brain AlJ. The laryngeal mask - a new concept in airway management. Br J Anaesth 1983; 55: 801-5.

2 Brain AIJ. The Intavent Laryngeal Mask Instruction Manual, 2nd ed. Henley on Thames: Intavent, 1993; 7.

3 Brown GW, Patel N. Ellis FR. Comparison of propofol and thiopentone for laryngeal mask insertion. Anacsthesia 1991; 46: 771-2.

4 Scanlon P, Carey M, Power M, Kirby F. Patient response to laryngeal mask insertion after induction of anaesthesia with propofol or thiopentone. Can J Anaesth 1993; 40: 816-8.

5 Brimacombe J, Berry A. Insertion of LMA - an indication for propofol? Anaesth Intensive Care 1992; 20: 394-5.

6 McKeating K, Bali IM, Dundee JW. The effects of thiopentone and propofol on upper airway integrity. Anaesthesia 1988; 43: 638-40.

7 Wilson IG, Fell D, Robinson SL, Smith G. Cardiovascular responses to insertion of the laryngeal mask. Anaesthesia 1992; 47: 300-2.

8 Poulton TJ, James FM III. Cough suppression by lidocaine. Anesthesiology 1979; 50: 470-2.

9 Steinhaus JE, Gaskin L. A study of intravenous lidocaine as a suppressant of cough reflex. Anesthesiology 1963, 24; 285-90.

10 Abou-Madi MN, Keszler H, Yacoub JM. Cardiovascular reactions to laryngoscopy and tracheal intubation following small and large intravenous doses of lidocaine. Can Anaesth Soc J 1977; 24: 12-9.

11 Hamill JF, Bedford RF, Weaver DC, Colohon AR. Lidocaine before endotracheal intubation: intravenous or laryngotracheal? Anesthesiology 1981; 55: 578-81.

12 Stoneham MD, Bree SE, Sneyd JR. Facilitation of laryngeal mask insertion. Effects of lignocaine given intravenously before induction with propofol. Anaesthesia 1995; $50: 464-6$.

13 Short TG. Galletly DC. Plummer JL. Hypnotic and anaesthetic action of thiopentone and midazolam alone and in combination. Br J Anaesth 1991; 66:13-9.

14 Reves JG, Fragen RJ, Vinik HR, Greenblatt DJ. Midazolam: pharmacology and uses. Anesthesiology 1985; 62: 310-24.

15 Harrison $G A$. The influence of different anaesthetic agents on the response to respiratory tract irritation. $\mathrm{Br} \mathrm{J}$ Anaesth 1962; 34: 804-11. 